\title{
Ekspresi Gen Tissue Inhibitor Metalloproteinase-1 Pada Sel Sinoviosit Osteoartritis Grade IV Setelah Pemberian Diacerein
}

\author{
Vivi Sofia ${ }^{1}$, Hirowati Ali $^{2}$, Rizki Rahmadian ${ }^{3}$, Fitri Amita ${ }^{4}$
}

\begin{abstract}
Abstrak
Disease Modifying Osteoarthritis Drugs (DMOADs) merupakan agen yang dapat mencegah, menghambat perkembangan atau mengembalikan perubahan morfologi pada penderita osteoarthritis. Salah satu yang termasuk DMOADs ini adalah diacerein. Diacerein menstimulasi terbentuknya Tissue Inhibitor Metalloproteinase-1 (TIMP-1) pada percobaan hewan. Tujuan penelitian ini adalah mengetahui pengaruh penggunaan diacerein pada ekspresi gen TIMP-1 pada sel primer jaringan sinovial pasien osteoartritis. Pada penelitian ini dilakukan penambahan diacerein pada sel primer jaringan sinovial grade 4. Ekspresi gen dilihat dengan menggunakan alat Real Time PCR dari sampel yang telah diinkubasi dalam kurun waktu 24 jam dan 48 jam, kemudian dibandingkan dengan kontrol menggunakan metode $\Delta \mathrm{C}_{\mathrm{T}}$ dengan GAPDH sebagai housekeeping gene. Dari hasil pengukuran ekspresi gen sampel 24 jam dan 48 jam didapatkan nilai berturut-turut 0,0179 dan 0,7423 dengan nilai kontrol 0,0005. Berdasarkan hasil penelitian, diketahui bahwa pada inkubasi diacerein selama 24 jam mampu meningkatkan ekspresi gen TIMP-1 dengan peningkatan sebesar 5,87 kali dibandingkan kelompok kontrol, sedangkan pada inkubasi selama 48 jam, diacerein mampu meningkatkan ekspresi gen TIMP-1 dengan peningkatan sebesar 1,53 kali jika dibandingkan dengan kelompok kontrol. Pada penelitian ini dapat disimpulkan bahwa overekspresi gen TIMP-1 berkaitan dengan pemberian diacerein pada osteoartritis.
\end{abstract}

Kata kunci: diacerein, osteoarthritis, tissue inhibitor metalloproteinase-1, jaringan sinovial

\begin{abstract}
Disease Modifying Osteoarthritis Drugs (DMOADs) are agents that could prevent, inhibit the progression of morphological changes or restore in patient with osteoarthritis. One of DMOADs is diacerein. Diacerein has effect increased Tissue Inhibitor Metalloproteinase-1 (TIMP-1) on animal model. The objective of this study was to explore the influence of diacerein on lowering gene expression TIMP-1 of primary cell in synovial tissues on the patient with osteoarthritis grade IV. This research was conducted with addition of diacerein in synovial tissues of primary cell grade 4. Gene expression of the samples that had been incubated for 24 hours and 48 hours were known by using Real Time PCR then those had been compared with the control using $\triangle C T$ with gene reference method. Based on the result it can concluded that the value og gene expression of samples at 24 and 48 hours of incubation respectively were 0.0179 and 0.7423 with control value was 0.0005 . Based on result of the research, it is known that 24 hours of incubation was increased gene expression of TIMP-1 more 5,87 times if compared with the control group, while that 48 hours of incubation was increased gene expression of TIMP-1 more 1, 53 times if compared with the control group. This research can be concluded that the over expression of TIMP-1 associated with the given Diacerein of the synoviocyte cell of osteoarthritis.
\end{abstract}

Keywords: diacerein, osteoarthritis, tissue inhibitor metalloproteinase-1, synovial tissues

Affiliasi penulis: 1.Fakultas Farmasi Universitas Ahmad Dahlan, 2. Bagian Biokimia Fakultas Kedokteran Universitas Andalas (FK Unand), 3. Bagian Bedah FK Unand, 4. Fakultas Farmasi Universitas Andalas
Korespondensi: Vivi Sofia, Email: vi2_sophia@yahoo.co.id

Telp: 081328327140 


\section{PENDAHULUAN}

Osteoartritis lutut merupakan sekelompok kondisi heterogen pada sendi lutut yang ditandai dengan adanya proses degradasi, reparasi disertai inflamasi yang terjadi pada jaringan ikat, lapisan rawan sendi, sinovium dan tulang subkondral. Menurut World Health Organization (WHO) pada tahun 2004 diketahui bahwa prevalensi penderita osteoartritis di dunia mencapai 151,4 juta jiwa dan sekitar 27,4 juta jiwa berada di kawasan Asia Tenggara. Data World Health Organization di Indonesia tercatat $8,1 \%$ penduduk mengalami gangguan $\mathrm{OA}$ dari total jumlah penduduk. Diperkirakan 1 sampai 2 juta orang lanjut usia di Indonesia menderita cacat karena osteoartritis dan diketahui prevalensi penyakit osteoartritis lutut pada pasien wanita berumur 75 tahun ke atas dapat mencapai $35 \%$ dari jumlah kasus yang ada. ${ }^{1}$

Terapi yang dapat menyembuhkan osteoartritis dengan hasil yang memuaskan belum ditemukan sampai saat ini. $^{2}$ Terapi farmakologi pada penatalaksanaan OA banyak menimbulkan masalah gangguan kesehatan baru akibat efek samping yang ditimbulkan dari pemakaian obat-obat jangka panjang, seperti halnya penggunaan Non Steroidal Anti Inflammatory Drugs (NSAID's) jangka panjang akan mengakibatkan tukak lambung dan gangguan fungsi ginjal. Untuk terapi non farmakologi berupa operasi pengganti sendi hanya dilakukan untuk penderita dengan $\mathrm{OA}$ yang berat dan tidak respon dengan pengobatan secara farmakologi. ${ }^{3}$

Pada tingkat molekuler, ketidakseimbangan antara aktivitas katabolik dan anabolik dimana respon injuri yang utama terjadi pada tulang rawan sendi mengakibatkan terjadinya osteoartritis. Ekspresi dari beberapa gen yang terlibat dalam respon inflamasi dan degradasi kartilago, seperti Interleukin 1 (IL-1) , Tumor Necrosis Factor Alfa (TNF- $\alpha){ }^{4}$

Enzim yang bertanggung jawab terhadap degradasi kartilago adalah Matrix Metalloproteinase (MMP), enzim ini disekresi baik oleh sel sinovial maupun kondrosit dan digolongkan ke dalam tiga golongan umum, yaitu collagenase, stromelysin dan gelatinase. Beberapa keadaan seperti trauma atau jejas mekanik akan menginduksi pelepasan enzim degradasi, seperti stromelysin dan MMP lain.
Stromelisin mendegradasi proteoglikan, sedangkan MMP mendegradasi proteoglikan dan kolagen. MMP diproduksi oleh kondrosit, kemudian diaktifkan melalui kaskade yang melibatkan proteinase serin (aktivator plasminogen), radikal bebas dan beberapa MMP tipe membran yang berperan pada osteoartritis yaitu MMP1, MMP3, MMP 9 dan MMP 13. MMP mempunyai kemampuan degradasi seluler secara lengkap, sehingga keberadaannya dikontrol secara ketat oleh inhibitornya. Kaskade enzimatik ini dikontrol oleh berbagai inhibitor, termasuk Tissue Inhibitor of Metalloproteinase (TIMPs) dan inhibitor aktivator plasminogen. TIMPs umumnya berfungsi menghambat MMP, tidak dapat bekerja optimal karena di dalam rongga sendi ini cendrung bersifat asam oleh karena pengaruh stromelisin $(\mathrm{pH} 5,5)$, sementara TIMPs baru dapat bekerja optimal pada $\mathrm{pH} 7,5$. Keseimbangan antara MMP dan TIMPs ini dikendalikan oleh IL-1. Saat enzim MMP melakukan aktivitas degradasi matriks, maka ditemukan pula kadar TIMPs yang meningkat, namun tidak cukup mengimbangi peningkatan dari hidrolisis enzim MMP tersebut, kegagalan kontrol inilah yang dapat menyebabkan osteoartritis. ${ }^{5}$

Pada osteoartritis, respon kondrosit akibat adanya perubahan biomekanikal dan biokimia yaitu berupa terbentuknya MMP-3 yang merupakan enzim degradatif yang tidak diimbangi oleh kerja inhibitornya yaitu TIMPs, sehingga terjadilah pembentukan matriks dengan kulaitas yang tidak baik. Perubahan pada tulang rawan iniakan menyebabkan juga perubahan pada tulang subkondral yaitu berupa penebalan dan peningkatan densitas mineral tulang yang secara radiologi akan terlihat pada daerah subkondral berupa sklerosis dan gambaran osteofit. ${ }^{6}$

TIMPs ini disekresikan oleh berbagai sel termasuk sel otot polos dan makrofag. Aktivitasnya ditingkatkan oleh PDGF dan TGF- $\beta$. Aktivasi MMP dalam bentuk inaktif (zymogen) dapat terjadi di intraseluler dan pada permukaan sel dan di ruang ekstraselluler melalui aksi dari protease lain atau bahkan dari MMP sebelumnya yang sudah aktif. ${ }^{7}$ Beberapa upaya terapi lain juga dilakukan seperti penelitian mengenai disease-modifying osteoarthritis drug (DMOADs) untuk memperbaiki struktur dan 
fungsi tulang rawan serta jaringan disekitarnya. Hasil penelitian sebelumnya, penggunaan DMOADs pada penderita osteoartritis dapat memperlambat laju perkembangan penyakit, menghentikan perkembangan penyakit, regenerasi jaringan target dan bahkan mencegah perkembangan penyakit. Salah satu obat yang termasuk DMOADs (Disease Modifying Osteoarthritis Drugs) ini adalah diacerein. Diacerein pertama kali dirilis di Italia tahun 1970 yang merupakan di-asetat derivatif dari Rhein yaitu molekul dengan cincin anthraquinonic. Rhein memiliki sifat anti-inflamasi melalui penghambatan interleukin-1, sitokin yang sangat terlibat dalam proses degeneratif tulang rawan. Penghambatan ini telah dikonfirmasi pada penelitian sebelumnya baik pada model hewan percobaan atau pada kultur sel kondrosit. ${ }^{8}$

Sel primer merupakan sel yang diperoleh secara langsung dari pemisahan jaringan suatu organisme melalui pemotongan jaringan normal dan dikultur. Kultur primer ini hanya dapat dipertahankan dalam periode waktu tertentu. Keunggulannya adalah lingkungan $(\mathrm{pH}$, suhu, nutrisi pertumbuhan) yang mudah diatur, dapat menggambarkan karakteristik sel, mudah diukur, dan lebih etis daripada menggunakan hewan percobaan. Kultur sel juga memiliki keterbatasan seperti mudah terkontaminasi, ketidakstabilan genetik dan fenotip, serta biaya pemeliharaan yang relatif mahal. ${ }^{9}$

Penelitian yang pernah dilakukan salah satunya adalah menggunakan sel primer lambung. Pembuatan kultur sel primer lambung ini dilakukan dengan cara mengisolasi kelenjar lambung dari jaringan perut yang sehat kemudian ditumbuhkan pada media yang mengandung matrigel dengan berbagai faktor pertumbuhan, regulator perkembangan dan inhibitor apoptosis untuk menghasilkan sel epitel lambung yang normal dan bertahan lama. ${ }^{10}$ Pada penelitian sel primer jaringan sinovial pada osteoarthritis dengan Hyaluronic Acid (HA) digunakan untuk melihat ekspresi gen connective tissue growth factor (CTGF), transforming growth factor-b1 (TGFb1), dan vascular endothelial growth factor (VEGF) yang terkait pada osteoarthritis. $^{11}$
Berdasarkan penjelasan diatas, perlu dilakukan penelitian lebih lanjut mengenai ekspresi gen Tissue Inhibitor Metalloproteinase-1 pada osteoartritis lutut grade IV dengan menggunakan diacerein pada sel primer jaringan sinovial.

\section{METODE}

\section{Isolasi Jaringan Sinovial}

Isolasi jaringan sinovial diawali dengan pembuatan aliquot primary cell culture atau medium komplit yang berisi DMEM, 20\% FBS, 1\% Penstrep dan $1 \%$ fungizone pada tube $50 \mathrm{ml}$ sebagai medium. Sampel yang telah di inkubasi selama 24 jam dipisahkan dengan menggunakan cell strainer, kemudian disentrifuse pada kecepatan 2000 rpm suhu $4^{\circ} \mathrm{C}$ selama 10 menit. Setelah disentrifuse akan terbentuk dua lapisan yaitu lapisan bawah pelet dan lapisan atas supernatan. Lapisan supernatan dibuang sehingga hanya pelet yang tersisa. Kemudian pelet di dilusi dengan $1 \mathrm{ml}$ medium. Pindahkan ke well dan tambah $2 \mathrm{ml}$ medium pada well. Setelah selesai masukkan ke inkubator $\mathrm{CO}_{2}$. Amati pertumbuhan sel 3 hari kemudian.

\section{Penambahan diacerein pada sel}

Sel yang telah dalam keadaan konfluens 70 $80 \%$, medium lama dibuang lalu duci dengan PBS. Setelah itu ditambahkan dengan diacerein $10 \mu \mathrm{g} / \mathrm{ml}$ dalam DMEM yang mengandung $1 \%$ penisilinstreptomisin dan $1 \%$ fungizone. Sebagai kontrol digunakan sel yang tidak ditambahkan diacerein.

\section{Perhitungan Sel}

Sel yang telah didilusi dan dihomegenisasi, diambil $10 \mu \mathrm{l}$ dan ditetesi pada hemocytometer. Sel dihitung pada $1 \mathrm{~mm}$ centre square yang terdiri dari 25 square (tiap square terdiri dari 16 square yang lebih kecil) dan 4x1 mm corner square.

Total sel $/ \mathrm{mL}=$ rata-rata jumlah sel per square $\times 10^{4}$

\section{Desain Primer}

Desain primer menggunakan software Primer

Plus 3. Spesifikasi primer dinilai dengan program BLAST. 


\section{Ekstraksi RNA dan sintesis cDNA}

RNA diekstraksi dari isolat jaringan sinovial pasien Osteoartritis grade IV. Isolasi RNA menggunakan TRIzol ${ }^{\circ}$ reagent literature, Invitrogen Life Technologies. Pembuatan cDNA menggunakan iScript cDNA Syntesis Kit (Bio-Rad iScript gDNA Clear cDNA synthesis Kit Catalog) pada alat Reverse Transcriptase PCR (RT-PCR) thermal cycler C1000 (Bio-Rad).

\section{Penentuan ekspresi TIMP-1}

Gen TIMP-1 diamplifikasi dengan menggunakan LightCycler® Fast Start DNA Master SYBR $®$ Green Kit (Roche) menggunakan mesin Real Time PCR LightCycler® 2.0-Time PCR Sistem Real, Bio $\operatorname{Rad} \circledast$.

Tahapan kerja Real Time PCR terdiri dari 3 langkah, yaitu denaturasi template DNA, amplifikasi target dan melting curve. Suhu denaturasi ditetapkan pada $95^{\circ} \mathrm{C}$ pada tingkat denaturasi awal, denaturasi amplifikasi dan denaturasi melting curve, suhu annealing dioptimasi pada rentang $55,7-63,7^{\circ} \mathrm{C}$ selama 5 detik (optimum $57,3^{0} \mathrm{C}$ ).

\section{Tabel 1. Tahapan real time PCR}

\begin{tabular}{ll}
\hline Denaturasi awal & $95^{\circ} \mathrm{C}$ selama 10 menit \\
\hline Amplifikasi DNA target & \\
Denaturasi & $95^{\circ} \mathrm{C}$ selama 10 detik \\
Annealing & optimasi pada $55,7-$ \\
& $63,7^{\circ} \mathrm{C} \quad$ selama 5 \\
& detik (optimum $\left.57,3^{\circ} \mathrm{C}\right)$ \\
& \\
Melting curve & $65-95^{\circ} \mathrm{C}$, naik $0,5^{\circ} \mathrm{C}$ \\
& setiap 5 detik \\
\hline
\end{tabular}

Konsentrasi primer $0,5 \mu \mathrm{M}$ untuk masing-masing Forward dan Reverse.

\section{Analisa Data}

Hasil yang diperoleh diuji secara deskriptif.

\section{HASIL}

\section{Jumlah Sel}

Pertambahan jumlah sel dapat terlihat dari sesudah pengujian diacerein yaitu dengan jumlah sel awal $1 \times 10^{4}$ sel/well, setelah pengujian diacerein 24 jam diperoleh jumlah sel $11,5 \times 10^{4}$ sel dan pada 48 jam $13,25 \times 10^{4}$.

Hasil konsentrasi isolasi RNA dari sel primer jaringan sinovial menggunakan alat NanoDrop 2000 Spectrophotometer untuk setiap sampel adalah sampel 24 jam $(47,7 \mathrm{ng} / \mu \mathrm{L})$, sampel 48 jam $(39,85$ $\mathrm{ng} / \mu \mathrm{L})$, dan pada sampel kontrol (107,9 $\mathrm{ng} / \mu \mathrm{L})$.

\section{Desain primer dan amplifikasi gen target}

Pada penelitian ini, tingkat ekspresi gen ditujukan kepada gen Tissue Inhibitor Metalloproteinase-1 (TIMP-1) yang berperan pada patogenesis osteoartritis. Berdasarkan data dari Ensembl Genome Browser diketahui bahwa TIMP-1 terletak kromosom Xp11.3 pada posisi 47.582.31347.586.789. gen ini berukuran 624 bp.

Primer didesain dengan menggunakan software Primer 3 Plus. Sekuens primer diuji spesifitasnya dengan Basic Local Alignment Search Tool (BLAST). Hasil analisa elektroforesis dan melting peak pada grafik Real Time PCR menunjukkan hasil primer TIMP-1 adalah gen primer yang spesifik. Houseekeeping gene yang digunakan pada penelitian ini adalah GAPDH. Amplifikasi cDNA menggunakan iScript cDNA Syntesis Kit (Bio-Rad iScript gDNA Clear cDNA synthesis Kit Catalog) pada alat Reverse Transcriptase PCR (RT-PCR) thermal cycler C1000 (Bio-Rad). Amplifikasi dilakukandilakukan dengan komposisi primer $\mathrm{F}+$ Primer $\mathrm{R}+\mathrm{CDNA}+$ SYBR $®$ Green + iScript reverse reverse transcriptase dan Nuclease Free Water. Siklus PCR terdiri dari denaturas awal $95^{\circ} \mathrm{C}$, dilanjutkan dengan 39 kali siklus amplifikasi, masing-masing dengan denaturasi $95^{\circ} \mathrm{C}$ selama 5 detik, annealing pada suhu $57,3^{\circ} \mathrm{C}$.

Setelah dilakukan optimasi suhu untuk gen IL$1 \beta$ dan gen GAPDH, diperoleh suhu optimum annealing gen TIMP-1 adalah $57,3^{\circ} \mathrm{C}$, dan gen GAPDH adalah $60^{\circ} \mathrm{C}$. Kedua gen ini bisa running bersamaan pada PCR Real Time karena selisih suhu tidak lebih dari $5^{\circ} \mathrm{C}$. Primer yang digunakan spesifik untuk gen target dan suhu annealing yang digunakan sudah tepat. Proses ekstensi primer dilakukan pada suhu $72^{\circ} \mathrm{C}$, karena suhu tersebut merupakan suhu optimum polimerase DNA untuk proses PCR. 
Untuk memastikan bahwa gen TIMP-1 yang digunakan merupakan gen target yang spesifik maka dilakukan elektroforesis(Doc®Gel Electroforesis).

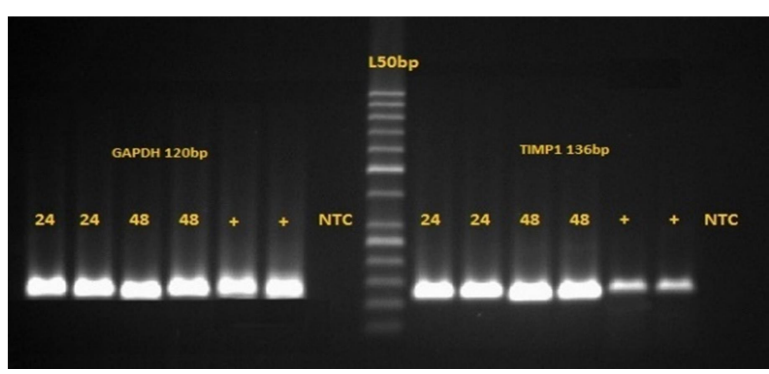

Gambar 1. Hasil elektroforesis gen TIMP-1

Tabel 2. Sekuens nukleotida gen TIMP-1 dan GAPDH

No Gen Sekuens nukleotida

1. TIMP-1 F: 5'ATGGACTCTTGCACATCACTAC3' R: 5'GGGATGGATAAACAGGGAAACA3'

2. GAPDH F: 5'ATGGGTGTGAACCATGAGAAGTA3' R: 5 'GGCAGTGATGGCATGGAC3`

\section{Tingkat ekspresi gen}

Ekspresi gen dianalisa dengan membandingkan nilai $\mathrm{Ct}$ gen target dengan housekeeping gene, sedangkan data kuantitatif didasarkan pada jumlah kopi (copy number) yang didapatkan dari perhitungan $\Delta \mathrm{C}_{\mathrm{T}}$. Analisa nilai ekspresi gen TIMP-1 dari realtime PCR menggunakan relative quantification. Metode $\Delta \mathrm{C}_{\mathrm{T}}$ dengan menggunakan gen referensi (Bio-Rad, 2000).

Ekspresi gen TIMP-1 diukur secara kuantitatif menggunakan Real Time PCR. Hasil dari reaksi Real Time PCR ini berupa nilai Threshold cycle (CT) yang menunjukkan siklus amplifikasi. Nilai $\mathrm{C}_{\mathrm{T}}$ mean untuk masing-masing sampel yaitu sampel 24 jam $(31,58)$, sampel 48 jam $(25,68)$ dan sebagai kontrol $(39,32)$. Dengan menggunakan metode $\Delta \mathrm{C}_{\mathrm{T}}$ dengan housekeeping gene diperoleh nilai ekspresi gen TIMP-1 untuk masing-masing sampel yaitu sampel 24 jam (0,01795), Sampel 48 jam $(0,74226)$ dan yang sebagai kontrol $(0,00054)$.
Tabel 3. Ekspresi gen TIMP-1 pada berbagai kelompok

\begin{tabular}{llll}
\hline Gen & kontrol & $\mathbf{2 4}$ jam & \multicolumn{1}{c}{ 48 jam } \\
\hline TIMP-1 & 38,31 & 30,71 & 24,84 \\
GAPDH & 28,45 & 25,78 & 24,25 \\
\hline
\end{tabular}

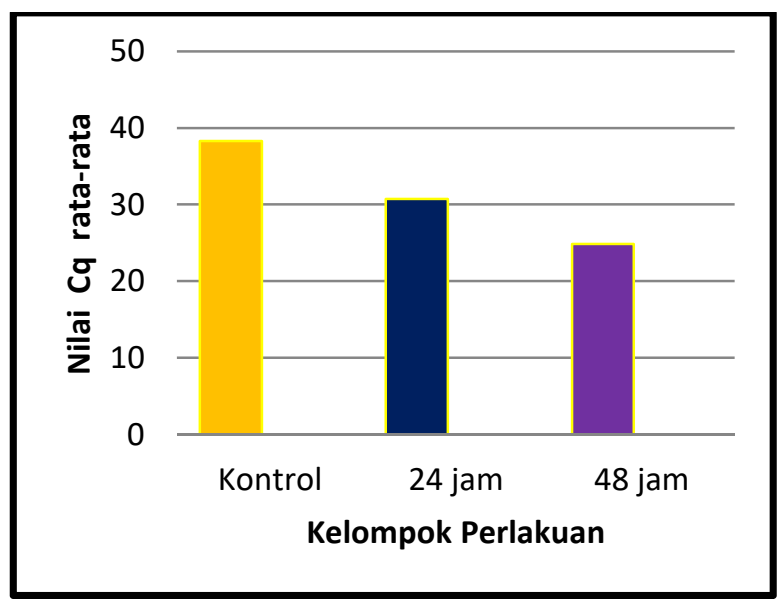

Gambar 2. Proporsi overekspresi dari gen TIMP-1 pada berbagai kelompok

\section{PEMBAHASAN}

Osteoarthritis merupakan penyakit radang sendi yang paling banyak ditemukan di dunia. Osteoartritis adalah penyebab disabilitas pada jutaan pasien, meliputi $60-70 \%$ orang yang berusia di atas 60 tahun. Kerusakan sendi menyebabkan terjadinya ketidakseimbangan antara proses sintesis dengan proses degradasi atau penghancurannya. ${ }^{12}$

Proses degradasi tulang rawan pada kartilago sendi disebabkan karena terjadinya peningkatan beberapa jenis matriks metalloproteinase, antara lain aggrekanase, kolagenase (seperti MMP1, 9, 13) dan gelatinase. Tissue Inhibitor Metalloproteinase-1 (TIMP1) merupakan salah satu dari 4 famili TIMPS yang bekerja menghambat aktivitas enzim metalloproteinase yang merusak matriks tulang rawan sendi (kartilago) pada osteoartritis. TIMP-1 merupakan regulator yang berperan penting pada proses turn over ekstraselluler matriks. Pada kasus osteoartritis, semakin meningkatnya progresivitas penyakit osteoartritis, maka ekspresi gen TIMP-1 akan menjadi 
semakin menurun dan ekspresi gen MMPs akan semakin bertambah. ${ }^{13}$ Berdasarkan penelusuran pustaka, masih sangat jarang penelitian yang mengamati ekspresi gen TIMP-1 ini pada jaringan sinovial pasien osteoartritis lutut grade 4 setelah pemberian diacerein yang merupakan salah satu obat osteoartritis dari golongan Disease Modyfing Osteoarthritis Drugs (DMOADs).

Penelitian ini didasarkan pada asumsi bahwa osteoartritis berkaitan dengan penurunan ekspresi gen TIMP-1 yang berperan dalam menghambat aktivitas enzim MMP. Diacerein adalah salah satu obat DMOADs yang banyak digunakan dalam penatalaksanaan OA. Diharapkan dengan pemberian diacerein pada kultur sel sinoviosit secara in vitro dapat meningkatkan ekspresi dari gen TIMP-1.

Hasil penelitian memperlihatkan gambaran yang bersesuaian dengan hipotesis awal dimana terdapat peningkatan ekspresi gen TIMP-1 setelah pemberian diacerein 24 dan 48 jam setelah diinkubasi dengan sel primer sinoviosit. Rerata $\Delta \mathrm{C}_{\mathrm{T}}$ gen TIMP-1 adalah sebesar 30,71 setelah diinkubasi 24 jam dan sebesar $\quad 24,84$ setelah inkubasi 48 jam. Angka ini lebih kecil dibandingkan dengan kelompok kontrol sebesar 38,31 .

Ekspresi gen dilihat dengan menggunakan alat Real Time PCR dari sampel yang telah diinkubasi dalam kurun waktu 24 jam dan 48 jam yang kemudian dibandingkan dengan kontrol menggunakan metode $\Delta \mathrm{C}_{\mathrm{T}}$ dengan GAPDH sebagai housekeeping gene. Setelah dilakukan analisa ekspresi gen diketahui bahwa pada inkubasi diacerein selama 24 jam mampu meningkatkan ekspresi gen TIMP-1 dengan peningkatan sebesar 5,87 kali dibandingkan kelompok kontrol, sedangkan pada inkubasi selama 48 jam, diacerein mampu meningkatkan ekspresi gen TIMP-1 secara bermakna dengan peningkatan sebesar 1,53 kali jika dibandingkan dengan kelompok kontrol. Pemberian Diacerein selama 48 jam tingkat ekspresi gen TIMP-1 lebih kecil jika dibandingkan dengan tingkat ekspresi gen setelah pemberian Diacerein selama 24 jam, hal ini mungkin disebabkan oleh semakin lama proses inkubasi Diacerein dapat menurunkan daya kerja Diacerein secara in vitro.

\section{SIMPULAN}

Terdapat peningkatan ekspresi gen TIMP-1 pada sel sinovial osteoartritis grade IV setelah pemberian diacerein.

\section{DAFTAR PUSTAKA}

1. World Health Organization (WHO). The global burden of disease 2004 Up-date. WHO Press, Switzerland. 2004

2. Rosemont. Treatment of osteoarthritis of the knee. American Academy of Orthopaedic Surgeons. Edisi ke-2; 2013.

3. Miller LE, II JF, Block JE. Quality of live in patients with knee osteoarthritis; a commentary on nonsurgical and surgical treatments. The Open Orthopaedics Journal. 2013; 7: 619-23.

4. Roman JA, Blas MD, Jimenez MD. NFk $\beta$ as a potential therapeutic target in osteoarthritis and rheumatoid arthritis, Review. Osteoarthritis Research Society International. Osteoarthritis and Cartilage. 2006;14:839-48.

5. Goldring SR, Goldring MB. Clinical Aspects: Pathology and pathophysiology of osteoarthritis. J Musculoskelet Neuronal Interact.2006:6(4):376-37.

6. Imbawan, EIGN, Putra, TR, dan Kambayana, G. Korelasi kadar matrix metalloproteinase 3 (MMP-3) dengan derajat beratnya osteoarthritis lutut. Journal Penyakit Dalam. 2011;12(3):181-192.

7. Creemers EEJM, Cleutjens JPM, Smith JPM, Daemen MJAP. Matrix metalloproteinase inhibition after myocardial infarction: a new approach to prevent heart failure? Circ Res. 2001; 89:281-90

8. Nicolas PM, Tod C, Padoin, Petitjean O. Clinical pharmacokinetics of diacerein. Clinical Pharmacokinetic. 1998;35:348-9.

9. Philippeos C, Hughes RD, Dhawan A, Mitry RR. Introduction to cell culture human cell culture protocols. Methods in Molecular Biology. 2012; 806(1):1-13.

10.Schlaermann P, Toelle B, Berger H, Schmidt SC, Glanemann M, Ordemann J. A novel human gastric primary cell culture system for modelling helicobacter pylori infection in vitro. Journal of Rheumatology. 2016;65:202-13. 
11.Yu-Tsang L, Hung-Jen S, Jyh-Horng W, HawChang L, Sheng-Mou H, Tai-Horng Y. Hyaluronic acid modulates gene expression of connective tissue growth factor (CTGF), transforming growth factor-b1 (TGF-b1), and vascular endothelial growth factor (VEGF) in human fibroblast-like synovial cells from advanced-stage osteoarthritis in vitro. Journal of orthopaedic research. 2009;492-6.
12.Jeffries M.A, Donica M, Baker LW, Stevenson ME, Annan AC, Humprey MB, Sawalha AH. GenomeWide DNA methylation study identifies significant epigenomic changes in osteoarthritis cartilage. Arthritis and Rheumatology. 2014;66(10):2804-15.

13.Wang M, Sampson ER, Jin H, Li J, Ke QH, Im HJ, et al. MMP13 is a critical target gene during the progression of osteoarthritis. Arthritis Res Ther. 2014;15:R5 